\title{
Ocimum basilicum L. Seeds Quality as Submitted to Saline Stress and Salicylic Acid
}

\author{
Toshik Iarley da Silva ${ }^{1}$, Jackson Silva Nóbrega ${ }^{2}$, Francisco Romário Andrade Figueiredo ${ }^{2}$, \\ Leonardo Vieira de Sousa ${ }^{2}$, João Everthon da Silva Ribeiro ${ }^{2}$, Riselane de Lucena Alcantara Bruno ${ }^{2}$, \\ Thiago Jardelino Dias $^{3} \&$ Manoel Bandeira de Albuquerque ${ }^{2}$ \\ ${ }^{1}$ Department of Plant Science, Federal University of Viçosa, Viçosa, Minas Gerais, Brazil \\ ${ }^{2}$ Department Plant Science and Environmental Sciences, Federal University of Paraíba, Areia, Paraíba, Brazil \\ ${ }^{3}$ Department of Agriculture, Federal University of Paraíba, Bananeiras, Paraíba, Brazil \\ Correspondence: Toshik Iarley da Silva, Department of Plant Science, Federal University of Viçosa, Viçosa, \\ Minas Gerais, Brazil. E-mail: iarley.toshik@gmail.com
}

Received: February 10, 2018

Accepted: March 11, $2018 \quad$ Online Published: April 15, 2018

doi:10.5539/jas.v10n5p159

URL: https://doi.org/10.5539/jas.v10n5p159

\begin{abstract}
The quality of the seeds is of great importance for the cultivation of plants, however, the quality can be altered by the abiotic effects, amongst such, saline stress. Salinity is one of the great obstacles faced by modern agriculture, however, alternatives have been researched to mitigate its effects, where it is possible to mention the use of salicylic acid. The objective of this study was to evaluate the quality of basil (Ocimum basilicum L.) seeds cultivated using applications of salicylic acid to attenuate the irrigation water salinity. The experimental design was a completely randomized complete block design in incomplete factor scheme, with five conductivities for irrigation water $\left(0.5,1.3,3.25,5.2,6.0 \mathrm{dS} \mathrm{m}^{-1}\right)$ and five salicylic acid doses $(0.0,0.29,1.0,1.71$ and $2.0 \mathrm{mM})$, with five and four replicates, respectively. The electrical conductivity presented an effect on germination, while the salicylic acid presented an effect on the germination speed index, emergence speed index, shoot length, root and seedling length, and seedlings dry mass. The highest correlations were obtained amongst the germination variables. Therefore, it is possible to affirm that salicylic acid can be used up to the dose of $1.0 \mathrm{mM}$ with no further damage to basil seeds' quality.
\end{abstract}

Keywords: saline water, salinity attenuation, vigor

\section{Introduction}

The seed's physiological quality can be influenced by biotic and abiotic factors, amongst such saline stress. With this regard, excess salt in addition to reducing the water absorption by the seeds also causes toxicity, which can lead to the death of the embryo (Santos et al., 2016). Under these conditions, basil (Ocimum basilicum L.), a species belonging to the botanical family Lamiaceae, involved in ornamental trade and spices (mainly due to the high linalool content present in the essential oil) presents germination and viability of seeds (McMahon et al., 2004).

Currently, alternatives are researched to attenuate the effects of saline stress on plants, amongst such alternatives, the salicylic acid (SA) attenuators are highlighted. This acid is a phenolic nature hormone, acting as a regulator of the plant development, which participates in several physiological plant processes and has been studied as attenuating to biotic and abiotic stresses (Taiz et al., 2017).

Salicylic acid plays an important role in the response to abiotic stresses, including water deficit, low temperature, and salt stress (Miura \& Tada, 2014). Several studies have been carried out using salicylic acid with a salt stress attenuator (Ashraf et al., 2010; Bahini et al., 2012; Jini \& Joseph, 2017).

Knowing that seed quality is a parameter of great importance in improving medicinal herbs yields and that salicylic acid can be used to mitigate the deleterious effects caused by saline stress. Thus, the objective of this study was to evaluate the quality of basil seeds (Ocimum basilicum L.) cultivated under the application of salicylic acid as an attenuation of the irrigation water salinity. 


\section{Material and Methods}

\subsection{Obtaining Basil Seeds}

The basil plants were cultivated in a under greenhouse conditions at the Agricultural Sciences Center of the Federal University of Paraíba located in the city of Areia, PB $\left(6^{\circ} 51^{\prime} 47^{\prime \prime} \mathrm{S}, 35^{\circ} 34^{\prime} 13^{\prime \prime} \mathrm{O}\right.$; $\left.575 \mathrm{~m}\right)$, during the months of May to August 2017.

The seeds used were from Cinnamon. The experimental units composed of polyethylene pots with $5.0 \mathrm{dm}^{-3}$ capacity were filled by soil collected at the experiment site together with $20 \mathrm{~g} \mathrm{dm}^{-3}$ of chicken manure. The soil used was classified as sandy-loamy Latosol with the following physical characteristics (EMBRAPA, 1997): sand $\left(\mathrm{g} \mathrm{kg}^{-1}\right): 756.9$; silte $\left(\mathrm{g} \mathrm{kg}^{-1}\right): 59.1$; clay $\left(\mathrm{g} \mathrm{kg}^{-1}\right): 184.0$; apparent density $\left(\mathrm{kg} \mathrm{dm}^{-3}\right): 1.38$; particle density $(\mathrm{kg}$ $\left.\mathrm{dm}^{-3}\right): 2.67$; total porosity (\%): 48 ; field capacity $\left(\mathrm{g} \mathrm{kg}^{-1}\right): 78$; permanent wilting point $\left(\mathrm{g} \mathrm{kg}^{-1}\right): 43$. A soil fertility sample was collected from soil and manure according to the methodology proposed by EMBRAPA (1997). The analysis presented the following characteristics: $\mathrm{pH}\left(\mathrm{H}_{2} \mathrm{O}\right): 6.9 ; \mathrm{P}\left(\mathrm{mg} \mathrm{dm}^{-3}\right): 11.71 ; \mathrm{K}^{+}\left(\mathrm{mg} \mathrm{dm}^{-3}\right): 87.43 ; \mathrm{Na}^{+}$ $\left.\left(\mathrm{cmol} \mathrm{dm}{ }^{-3}\right): 0.24 ; \mathrm{H}^{+}+\mathrm{Al}^{3+}\left(\mathrm{cmol} \mathrm{dm}^{-3}\right): 1.6 ; \mathrm{Al}^{3+}(\mathrm{cmol} \mathrm{dm})^{-3}\right): 0.00 ; \mathrm{Ca}^{2+}\left(\mathrm{cmol} \mathrm{dm}^{-3}\right): 4.65 ; \mathrm{Mg}^{2+}\left(\mathrm{cmol} \mathrm{dm}^{-3}\right)$ : 0.39; SB ( $\left.\mathrm{cmol} \mathrm{dm}^{-3}\right): 7.52 ; \mathrm{CTC}\left(\mathrm{cmol} \mathrm{dm}^{-3}\right): 9.12 ; \mathrm{V}(\%): 8.45 ; \mathrm{M} . \mathrm{O}\left(\mathrm{g} \mathrm{dm}^{-3}\right): 22.73$.

Irrigation was performed by drainage lisimetry as needed. The water with the desired electrical conductivities $(\mathrm{ECw})$ were prepared by adding a mixture of $\mathrm{NaCl}, \mathrm{CaCl}_{2} \cdot 2 \mathrm{H}_{2} \mathrm{O}$ and $\mathrm{MgCl}_{2} \cdot 6 \mathrm{H}_{2} \mathrm{O}$ salts (in the equivalent ratio of $7: 2: 1$, respectively) in water $\left(0.5 \mathrm{dS} \mathrm{m}^{-1}\right)$ from the experiment site. The treatments with saline waters started after transplanting the seedlings until the end of the experiment. For the doses preparation of salicylic acid, distilled water was used, adding $0.05 \%$ Tween 80 as surfactant, to improve plants absorption. The control treatment for this factor was prepared with distilled water and Tween 80 . The experimental design was in randomized blocks, with five electrical conductivities of irrigation water (ECw: 0.50, 1.30, 3.25, 5.20 and $6.00 \mathrm{dS} \mathrm{m}^{-1}$ ) and five doses of salicylic acid (SA: $0.00,0.29,1.00,1.71$ and $2.00 \mathrm{mM} \mathrm{L}^{-1}$ ), with five replicates and two plants per replicate, totaling in 9 combinations generated through the Central Composite Box (CCB) matrix (Table 1). The plants were sprayed (about $10 \mathrm{~mL}$ per plant) until thoroughly wetted with the salicylic acid solutions weekly for 21 days. At 120 days after planting the seeds were collected and stored for further quality analysis.

Table 1. Matrix of Central Composite Box (CCB)

\begin{tabular}{lll}
\hline Treatment & $\mathrm{ECw}\left(\mathrm{dS} \mathrm{m}^{-1}\right)$ & $\mathrm{SA}(\mathrm{mM})$ \\
\hline 1 & 5.20 & 1.71 \\
2 & 5.20 & 0.29 \\
3 & 1.30 & 1.71 \\
4 & 1.30 & 0.29 \\
5 & 3.25 & 0.00 \\
6 & 3.25 & 2.00 \\
7 & 0.50 & 1.00 \\
8 & 6.00 & 1.00 \\
9 & 3.25 & 1.00 \\
\hline
\end{tabular}

\subsection{Basil Seeds Quality Evaluation}

\subsubsection{Experimental Design and Treatments}

The experiment was carried out at the Laboratory of Seed Analysis (LAS), at the Agricultural Sciences Center, in the Federal University of Paraíba (CCA-UFPB), Areia, PB. The seeds water content was determined using the oven method at $105 \pm 3{ }^{\circ} \mathrm{C}$ for 24 hours, using four replicates of five grams of seeds, according to Brasil (2009).

The germination test was performed using a completely randomized design, with four 50 seeds replicates, and the seeds were sowed in blotting paper inside germination acrylic boxes, moistened with distilled water $(2.5$ times the weight of the dried paper) and placed in a BOD (Biochemical Oxygen Demand) type germination chamber regulated at a constant temperature of $25^{\circ} \mathrm{C}$ and 12 hours photoperiod. The germination was evaluated from the $4^{\text {th }}$ to the $15^{\text {th }}$ day after the test, considering the seeds germination that presented radicle protrusion and the two primordia leaves, with the results expressed as percentage of normal seedlings (Brasil, 2009).

The first germination count was performed on the $4^{\text {th }}$ day after the germination test, and the results were expressed as a percentage of normal seedlings. The germination rate index was obtained through daily counts of the number 
of seeds that produced normal seedlings, calculating results using the formula proposed by Maguire (1962). The average germination time was established through daily counts of normal seedlings on each day of the germination test, calculated using the formula proposed by Labouriau (1983).

The seedling emergence assay was performed in a greenhouse, and four 50 seeds replicates were used, where such were seeded in plastic trays with a seven liters capacity, containing as substrate washed and sterilized sand. The percentage of emergent seedlings was evaluated daily by counting the seedlings that presented visible cotyledons above the substrate, performed until the $15^{\text {th }}$ day after sowing, with results expressed as a percentage. The emergence speed index was obtained via daily counts of the number of seedlings emerged, calculated using the formula proposed by Maguire (1962).

At the end of the emergence test, the length of root, shoot and seedling length was evaluated, taking into consideration the hypocotyl and epicotyl. The seedling length was obtained based on the sum of the root and shoot length values, using a millimeter ruler, and the results were expressed in centimeters $(\mathrm{cm})$.

The dry mass was created by packing the seedlings in kraft-type paper bags and drying them in an oven equipped with air circulation at $65^{\circ} \mathrm{C}$ until reaching constant weight. The weighing was performed in an analytical scale with a 0.001 grams accuracy, and results were expressed as grams $(\mathrm{g})$ seedling $^{-1}$.

\subsubsection{Statistical Analysis}

Data was further submitted to variance analysis and when significant, a regression analysis was performed. We also performed a correlation analysis between the factors and variables analyzed, all of such using the statistical software R (R Core Team, 2017). Only the data that presented significant results were submitted to regression analysis and presented in the discussion.

\section{Results and Discussion}

The initial water content for basil (Ocimum basilicum L.) seeds varied by 0.97 percentage points ( 8.9 to $9.95 \%$ ), cultivated according to different saline levels and salicylic acid doses, whereas such values are within tolerable limits between samples (Table 2). According to Marcos Filho (2015), the maximum variation limit is $2.5 \%$, indispensable to the uniformity in the water content of the seeds, allowing obtaining results that are more coherent.

Table 2. Initial water content for basil (Ocimum basilicum) seeds, produced under different saline levels and salicylic acid doses

\begin{tabular}{llll}
\hline Treatment & $\mathrm{ECw}\left(\mathrm{dS} \mathrm{m}^{-1}\right)$ & $\mathrm{SA}(\mathrm{mM})$ & Water content $(\%)$ \\
\hline 1 & 5.20 & 1.71 & 9.73 \\
2 & 5.20 & 0.29 & 9.74 \\
3 & 1.30 & 1.71 & 10.18 \\
4 & 1.30 & 0.29 & 9.54 \\
5 & 3.25 & 0.00 & 9.60 \\
6 & 3.25 & 2.00 & 9.50 \\
7 & 0.50 & 1.00 & 9.16 \\
8 & 6.00 & 1.00 & 9.49 \\
9 & 3.25 & 1.00 & 8.28 \\
\hline
\end{tabular}

Note. $\mathrm{ECw}=$ Electrical conductivity for irrigation water; $\mathrm{SA}=$ salicylic acid.

A significant interaction was observed between the factors electrical conductivity for irrigation water (ECw) and salicylic acid (SA) in relation to the percentage of germination. However, ECw demonstrated no effects on the other variables.

Germination is one of the most crucial and decisive phases in the plant growth cycle, since it determines the establishment and final yield of the plant (Bahrai \& Pourreza, 2012). Germination can be affected by several biotic and abiotic factors, such as saline stress, however, the application of phytohormones may attenuate such effects. In the current study herein presented, the application of salicylic acid in the basil growth phase favored the germination of seeds produced by these plants (Figure 1). 


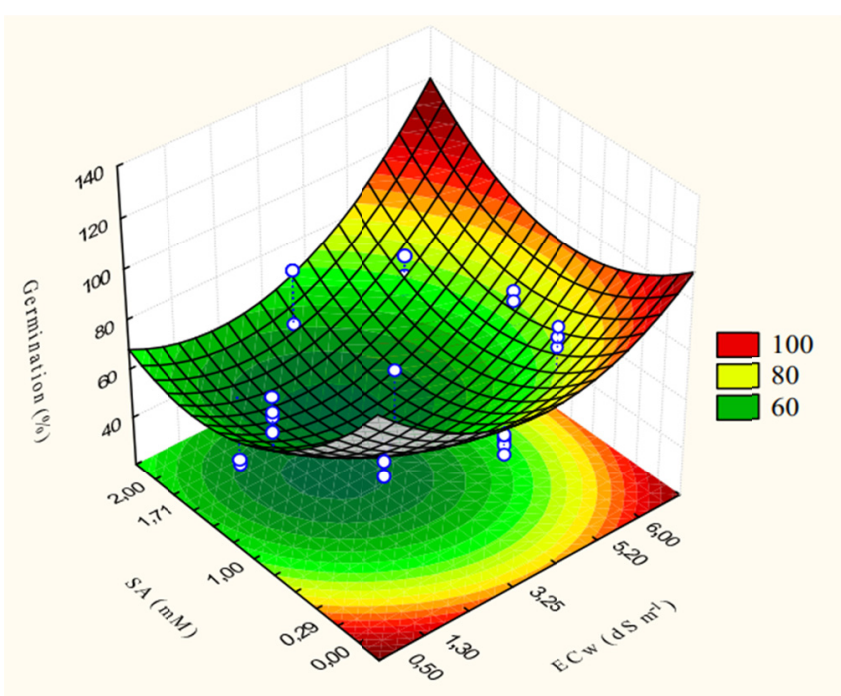

Figure 1. Germination of basil (Ocimum basilicum) seeds cultivated with different levels of electrical conductivity of irrigation water (ECw) and salicylic acid doses (SA)

The utilization of salicylic acid attenuated the effect of saline stress on basil germination. The highest germination percentages were obtained in a concentration of $0.29 \mathrm{mM}$ in 0.5 and $5.2 \mathrm{dS} \mathrm{m}^{-1}$; however, above 1.0 $\mathrm{mM}$, there was a decrease in the germinated seeds percentage (normal seedlings), where such were the lowest values obtained when $1.71 \mathrm{mM}$ AS and ECw of $3.25 \mathrm{dS} \mathrm{m}^{-1}$ were applied. Salicylic acid plays an important role in free radicals elimination, acting in slowing down or inhibiting the lipids oxidation in cell membranes. Its exogenous application is used by seeds to adapt to stress, since it can act stimulating the expression and strengthening the cell wall barrier properties, directing the phosphate and chiquimate pentoses routes for the production of phenolic compounds (lignin and suberin) which may confer seed vigor maintenance (Agostini et al., 2013; Tonel et al., 2013).

The salinity reduces and delays germination, decreasing water absorption and causing toxicity in the embryo (Reyes-Pérez et al., 2013). These authors evaluated the germination of basil cultivars under saline stress, which emphasize that the cultivar Cinnamon (the same one used in the current study) reducing the germination by $16.7 \%$ when $100 \mathrm{mM} \mathrm{NaCl}$ was applied. Mousavi and Jouyban (2012) report that salinity increase up to $8 \mathrm{dS} \mathrm{m}^{-1}$ resulted in a $30.2 \%$ loss in basil germination.

For the germination rate, a quadratic effect is observed as a function of salicylic acid doses (Figure 2A). However, the highest increase occurred in the $0 \mathrm{mM}$ dose, with a reduction in the seeds germination speed with the doses increase, registering the lowest seeds vigor in the $1.0 \mathrm{mM}$ dose. This effect can be promoted as a function of a possible allelopathic effect caused by salicylic acid, and may even promote cell death within the seed (Tonel et al., 2013).
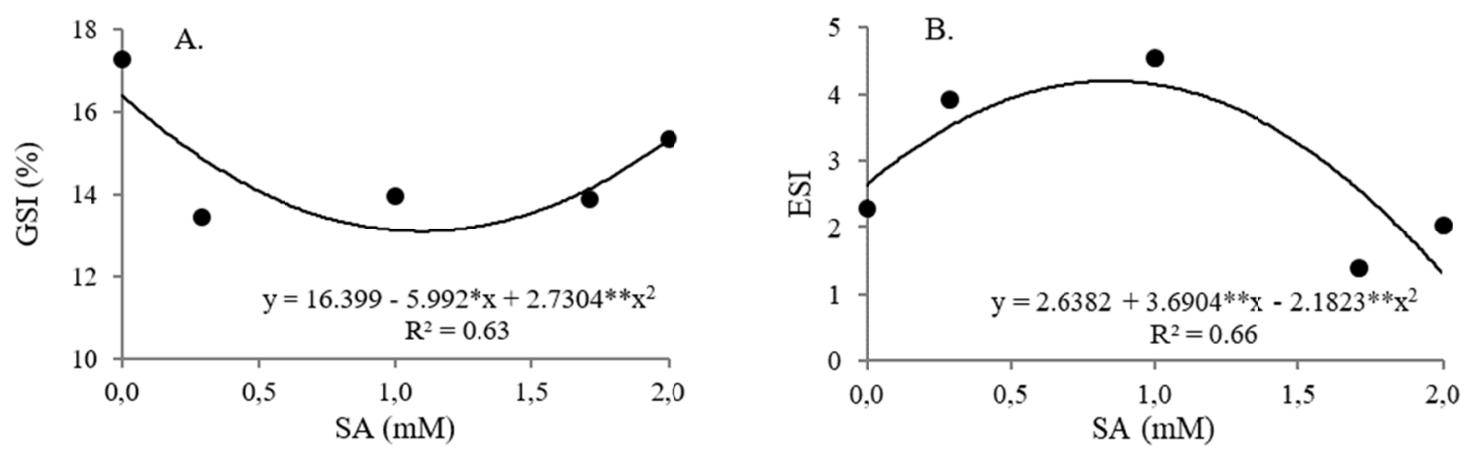

Figure 2. Germination speed index (GSI) (A) and emergence speed index (ESI) (B) of basil seeds (Ocimum basilicum) seeded with application of salicylic acid (SA) 
Salicylic acid can play several activities throughout plant metabolism, and may promote effects that favor plant growth or allelopathic effects. Among these functions, salicylic acid can inhibit seeds germination or hamper the germination process (Ashraf et al., 2010).

The results observed in the current study are in agreement with those obtained for other species such as chamomile seeds-Chamomilla recutita L. Rauschert (Pacheco et al., 2007), calendula-Calendula officinalis L. (Carvalho et al., 2007), maize-Zea mays L. (Tonel et al., 2013) and sorghum-Sorghum bicolor L. Moench (Lisboa et al., 2017).

The values obtained for the rate of emergence were adjusted to the quadratic effect with the increase in seedling velocity up to the $1.0 \mathrm{mM}$ dose, from that molarity the decrease occurs with increasing doses (Figure 1B). This increase occurs as a function of salicylic acid activity, which promotes a series of effects from germination to plant development. The fact that the emergence rate was different from the results found for the germination rate may be related to the conditions under which they were conducted, since this was performed in a controlled environment, unlike the other one. Salicylic acid is a phenolic compound that acts increasing cell wall lignification, due to the pentoses-phosphate and chiquimate routes for lignin production, resulting in seeds with higher vigor (Pacheco et al., 2007), and consequently, promotes the increase in seedlings emergence speed.

The stimulatory effect on the seedlings emergence is observed by several authors, such as melon-Cucumis melo L. (Moreira et al., 2014), cucumber-Cucumis sativus L. (Bertoncelli et al., 2015), and rice-Oryza sativa L. (Wang et al., 2016).

Comparing the effects of the different salicylic acid concentrations on the seeds, we observed a quadratic behavior for the following variables: root length, shoot length, seedling length and seedlings dry mass, with doses which induced maximum vigor was $0.95,0.92,0.93$ and $0.88 \mathrm{mM} \mathrm{SA}$, respectively (Figure 3). From the moment the doses were increased, there was a decrease in seedlings growth. High concentrations of salicylic acid may promote toxic effects, inducing the occurrence of oxidative stress, reducing plant growth (Hao et al., 2012).
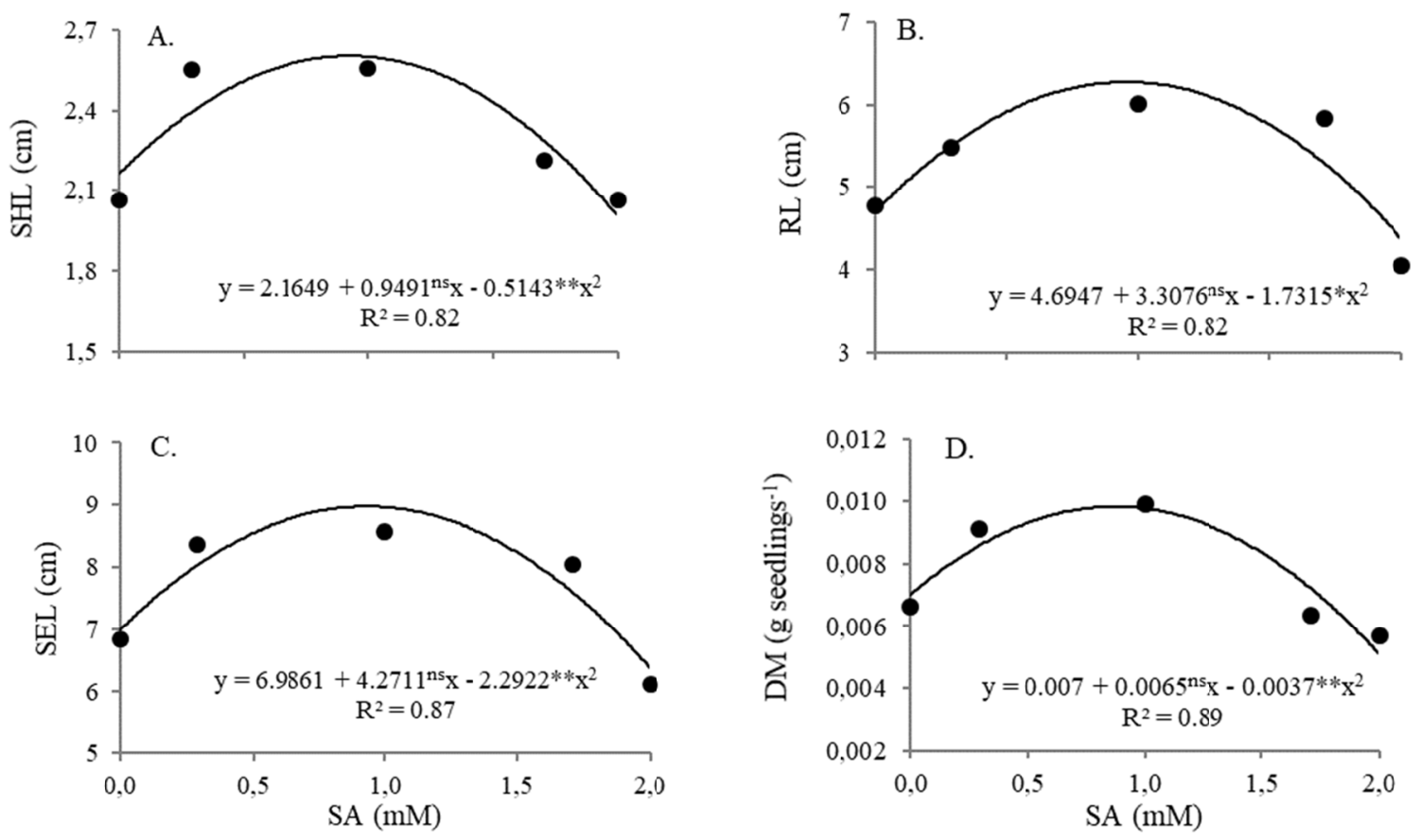

Figure 3. Shoot length (SHL) (A), root length (RL) (B) and seedling length (SEL) (C) and dry mass (DM) (D) of basil (Ocimum basilicum) seedlings cultivated with salicylic acid application (SA)

With regards to the aerial portion, root and seedlings growth, such had a maximum increase as a function of the salicylic acid $1.0 \mathrm{mM}$ dose, with an increase of $0.44 ; 1.58$ and 1.99 centimeters $(\mathrm{cm})$ in comparison to the lower dose (Figures 3A, 3B and 3C, respectively). This was because salicylic acid is considered a plant growth 
hormone, allowing for greater seedlings development. Salicylic acid is a phenolic compound that plays important roles in the plant, regulating plant growth, developing and defending the plant against stress conditions (Miura \& Tada, 2014). This stimulating behavior in the growth until the tolerated levels is verified in other vegetal species, as in cucumber - Cucumis sativus L. (Hao et al., 2012), wheat - Triticum aestivum L. (Kang et al., 2013), mustard - Sinapis alba L. (Nazar et a., 2015) and rice - Oryza sativa L. (Jini \& Joseph, 2017).

The seedlings dry mass (Figure 3C) presented the same behavior for seedlings length (Figure 3C), with an increase in biomass as a function of salicylic acid doses, being the highest values obtained in seedlings grown under $1.0 \mathrm{mM}$ doses, thereafter a decrease in dry seed biomass content for the seedlings occurred. In addition, the biomass accumulation as a function of the salicylic acid application allows the plant to sustain growth even under adverse conditions, promoting greater proteins expression involved in the photosynthesis and plant defense metabolism (Sharma et al., 2017).

According to Mazzuchelli (2014), these increases in biomass production may be related to the direct salicylic acid action on a specific tissues differentiation and also the growth of plant organs. It is noted that salicylic acid promoted an increase in biomass production to a certain extent, followed by a decrease with increasing doses. This may be due because such acts as a hormone antagonistic to auxin, that is, when a high concentration in the cellular tissue tends to inhibit plant growth.

When correlation was performed between the variables (Figure 4), it was observed a high positive correlation between the germination variables and seedlings vigor expressed by their growth.

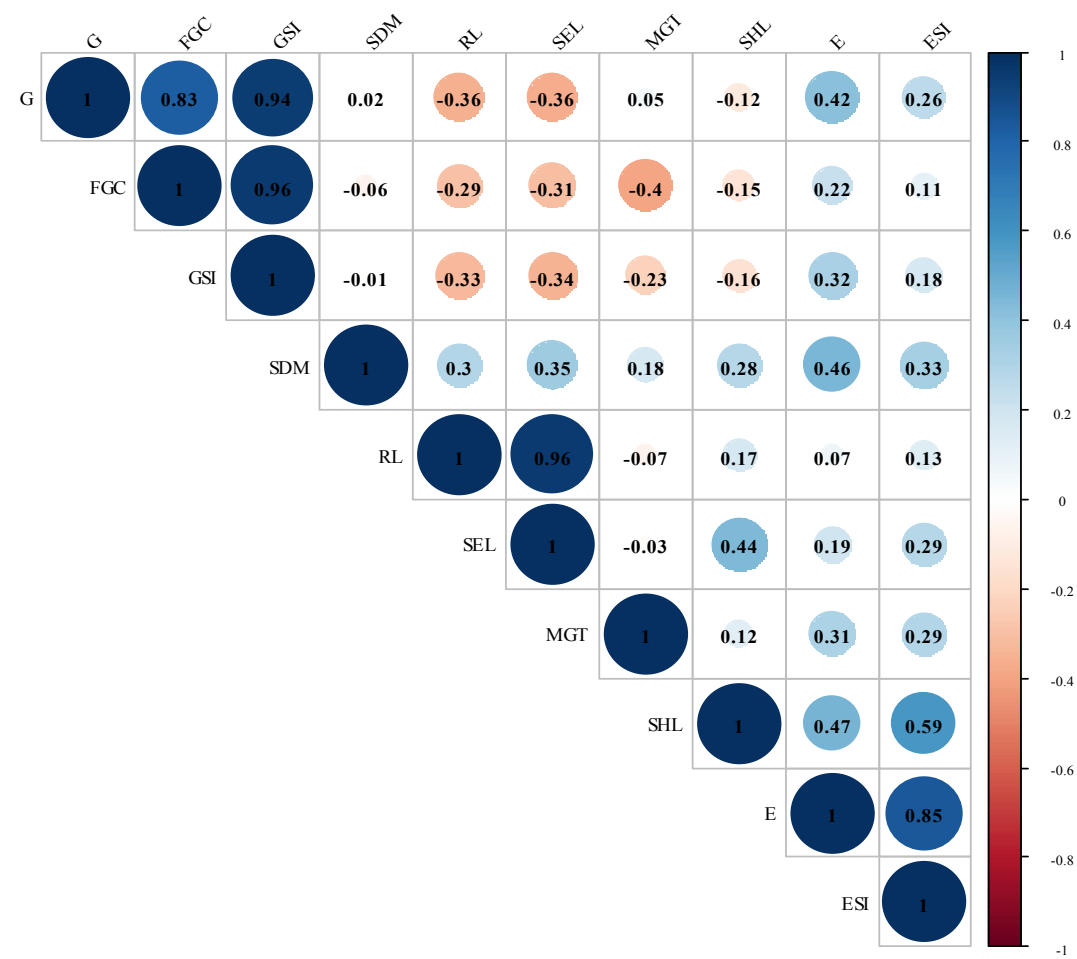

Figure 4. The Pearson correlation between germination (G), first germination count (FGC), germination speed index (GSI), mean germination time (MGT), root length (RL), shoot length (SHL), seedling length (SEL), emergence (E), emergence speed index (ESI) and seedling dry mass (SDM) of basil (Ocimum basilicum) subjected to saline stress and salicylic acid

The germination rate index was highly correlated with the first germination count (0.96). Regarding the emergence, it was observed it had a higher positive correlation with the emergence rate $(0.87)$. The highest positive correlations were determined between the first germination count and germination rate index $(0.96)$ and between root length and seedling length (0.96); and a negative correlation between the first germination count and the mean germination time (0.40). 


\section{Conclusions}

Salicylic acid and the electrical conductivity for irrigation water present an influence in the basil germination (Ocimum basilicum); the salicylic acid had a beneficial effect on seed quality, positively influencing seeds vigor as determined by tests comprehending germination speed index, emergency speed index, shoot length, root length, seedling length and seedlings dry mass; salicylic acid doses above $1.0 \mathrm{mM}$ present a toxic effect, reducing seeds vigor basil plants; the highest correlations were obtained amongst germination variables.

\section{References}

Agostini, E. A. T., Machado-Neto, N. B., \& Custódio, C. C. (2013). Induction of water deficit tolerance by cold shock and salicylic acid during germination in the common bean. Acta Scientiarum Agronomy, 35, 209-219. https://doi.org/10.4025/actasciagron.v35i2.15967

Ashraf, M., Akram, N. A., Arteca, R. N., \& Foolad, M. R. (2010). The physiological, biochemical and molecular roles of brassinosteroids and salicylic acid in plant processes and salt tolerance. Critical Reviews in Plant Sciences, 29, 162-190. https://doi.org/10.1080/07352689.2010.483580

Bahrani, A., \& Pourreza, J. (2012). Gibberlic acid and salicylic acid effects on seed germination and seedlings growth of wheat (Triticum aestivum L.) under salt stress condition. World Applied Sciences Journal, 18, 633-641. https://doi.org/10.5829/idosi.wasj.2012.18.05.1372

Bertoncelli, D. J., Mazaro, S. M., Rocha, R. C. D. S., Possenti, J. C., Rey, M. S., \& Zorzzi, I. C. (2015). Ácido salić́lico na indução de resistência a doenças em pepino e controle de Pythium sp. in vitro. Revista de Ciências Agroveterinárias, 14, 124-131. Retrieved from http://revistas.bvs-vet.org.br/rca/article/view/ $33101 / 36888$

Brasil. (2009). Regras para análise de sementes. Brasília, DF: Ministério da Agricultura, Pecuária e Abastecimento.

Çamlica, M., Yaldiz, G., \& Özen, F. (2017). Effects of Different Basil Hydrosol Doses on the germination and shoot and root lenghts of basil (Ocimum basilicum) and quinoa (Chenopodium quinoa) seeds. Indian Journal of Pharmaceutical Education and Research, 51, 254-257. https://doi.org/10.5530/ijper.51.3s.24

Carvalho, P. R., Machado Neto, N. B., \& Custódio, C. C. (2007). Uso de ácido salicílico em calêndula. Revista Brasileira de Sementes, 29, 114-124. https://doi.org/10.1590/S0101-31222007000100016

Embrapa. (1997). Manual de métodos de análise de solo (2nd ed.). Rio de Janeiro, RJ: Empresa Brasileira de Pesquisa Agropecuária.

Embrapa. (2014). Sistema Brasileiro de Classificação de Solos (4th ed.). Brasília, DF: Empresa Brasileira de Pesquisa Agropecuária.

Ferreira, S. D., Bulegon, L. G., Yassue, R. M., \& Echer, M. M. (2016). Efeito da adubação nitrogenada e da sazonalidade na produtividade de Ocimum basilicum L. Revista Brasileira de Plantas Medicinais, 18, 67-73. https://doi.org/10.1590/1983-084X/15_035

Ferreira, S. D., Echer, M. M., Bulegon, L. G., Pastório, M. A., Egewarth, V. A., Yassue, R. M., \& Achre, D. (2015). Influencia de la fertilización nitrogenada y la época de cultivo sobre el rendimiento de hojas de albahaca (Ocimum basilicum var. verde Toscana) con fines medicinales. Revista Cubana de Plantas Medicinales, 20, 389-396. Retrieved from http://scielo.sld.cu/pdf/pla/v20n4/pla03415.pdf

Hao, J. C., Dong, C. J., Zang, Z. G., Xang, X. L., \& Shang, Q. M. (2012). Insights into salicylic acid responses in cucumber (Cucumis sativus L.) cotyledons based on a comparative proteomic analysis. Plant Science, 87, 69-82. https://doi.org/10.1016/j.plantsci.2012.01.001

Jini, D., \& Joseph, B. (2017). Physiological mechanism of salicylic acid for alleviation of salt stress in rice. Rice Science, 24, 97-108. https://doi.org/10.1016/j.rsci.2016.07.007

Kang, G. Z., Li, G. Z., Liu, G. Q., Xu, W., Peng, X. Q., Wang, C. Y., ... Guo, T. C. (2013). Exogenous salicylic acid enhances wheat drought tolerance by influence on the expression of genes related to ascorbate-glutathione cycle. Biologia Plantarum, 57, 718-724. https://doi.org/10.1007/s10535-013-0335-z

Labouriau, L. G. (1983). A germinação das sementes. Washington, DC: Secretaria da OEA.

Lisboa, L. A. M., Lapaz, A. M., Viana, R. S., Leonezi, R. S., \& Figueiredo, P. A. M. (2017). Influência do ácido salicílico no processo germinativo de sementes de cultivares de sorgo sacarino. Acta Iguazu, 6, 37-49. Retrieved from http://saber.unioeste.br/index.php/actaiguazu/article/view/17446/11633 
Maguire, J. D. (1962). Speed of germination-aid in selection and evaluation for seedling emergence vigor. Crop Science, 2, 176-177. https://doi.org/10.2135/cropsci1962.0011183X000200020033X

Marcos Filho, J. (2015). Fisiologia de sementes de plantas cultivadas. Londrina, PR: ABRATES.

Mazzucchelli, E. H. L., Souza, G. M., \& Pacheco, A. C. (2014). Rustificação de mudas de eucalipto via aplicação de ácido salicílico. Pesquisa Agropecuária Tropical, 44, 443-450. https://doi.org/10.1590/S1983-4063201 4000400012

Miura, K., \& Tada, Y. (2014). Regulation of water, salinity, and cold stress responses by salicylic acid. Frontiers in Plant Science, 5, 1-12, 2014. https://doi.org/10.3389/fpls.2014.00004

Moreira, G. G., Viana, M. M., Lira, V. A., Guiscem, J. M., Santos, F. N., \& Rodrigues, E. F. (2014). Condicionamento fisiológico de sementes de melão com diferentes soluções de ácido giberélico e ácido salicílico. Horticultura Brasileira, 31, S3652-S3659. Retrieved from https://www.researchgate.net/profile/ Josiane_Guiscem/publication/280578110_Condicionamento_fisiologico_de_sementes_de_melao_com_dife rentes_solucoes_de_acido_giberelico_e_acido_salicilico/links $/ 55 \mathrm{bbad} 8108 \mathrm{ae} 9289 \mathrm{a} 09 \overline{5} 73 \overline{5} \mathrm{~b}$

Mousavi, S. G., \& Jouyban, Z. (2012). Effect of salinity stress on germination and growth parameters of seedlings of basil (Ocimum basilicum L.). Technical Journal of Engineering and Applied Sciences, 2, 84-87. Retrieved from http://jeas.com/wp-content/uploads/2012/10/84-87ok.pdf

Nazar, R., Umar, S., Khan, N. A., \& Sareer, O. (2015). Salicylic acid supplementation improves photosynthesis and growth in mustard through changes in proline accumulation and ethylene formation under drought stress. South African Journal of Botany, 98, 84-94. https://doi.org/10.1016/j.sajb.2015.02.005

Pacheco, A. C., Custódio, C. C., Machado Neto, N. B., Carvalho, P. R., Pereira, D. N., \& Pacheco, J. G. E. (2007). Germinação de sementes de camomila [Chamomilla recutita (L.) Rauschert e calêndula (Calendula officinalis L.) tratadas com ácido salicílico. Revista Brasileira de Plantas Medicinais, 9, 61-67. Retrieved from http://www.sbpmed.org.br/download/issn_07_1/artigo9_v9_n1.pdf

R Core Team. (2017). R: A language and environment for statistical computing. Viena, AU: R Foundation for Statistical Computing.

Reyes-Pérez, J. J., Murillo-Amador, B., Nieto-Garibay, A., Troyo-Diéguez, E., Reynaldo-Escobar, I. M., Rueda-Puente, E. O., \& García-Hernández, J. L. (2013). Tolerancia a la salinidad en variedades de albahaca (Ocimum basilicum L.) en las etapas de germinación, emergencia y crecimiento inicial. Universidad y Ciencia, 2, 101-112. Retrieved from http://www.scielo.org.mx/pdf/uc/v29n2/v29n2a1.pdf

Santos, C. A., Silva, N. V., Walter, L. S., Silva, E. C. A., \& Nogueira, R. J. M. C. (2016). Germinação de sementes de duas espécies da caatinga sob déficit hídrico e salinidade. Pesquisa Florestal Brasileira, 36, $219-224$. https://doi.org/10.4336/2016.pfb.36.87.1017

Sharma, M., Gupta, S. K., Majumder, B., Maurya, V. K., Deeba, F., Alam, A., \& Pandey, V. (2017). Salicylic acid mediated growth, physiological and proteomic responses in two wheat varieties under drought stress. Journal of Proteomics, 163, 28-51. https://doi.org/10.1016/j.jprot.2017.05.011

Taiz, L., Zeiger, E., Møller, I. M., \& Murphy, A. (2017). Fisiologia e desenvolvimento vegetal (6th ed.). Porto Alegre, RS: Artmed.

Tonel, F. R., Marini, P., Bandeira, J. M., Morais, D. M., \& Amarante, L. (2013). Salicylic acid: physiological and biochemical changes in seeds and maize seedlings subjected to salt stress. Journal of Seed Science, 35(4), 457-465. https://doi.org/10.1590/S2317-15372013000400007

Wang, W., Chen, Q., Hussain, S., Mei, J., Dong, H., Peng, S., ... Nie, L. (2016). Pre-sowing seed treatments in direct-seeded early rice: Consequences for emergence, seedling growth and associated metabolic events under chilling stress. Scientific Reports, 6, 19637. https://doi.org/10.1038/srep19637

\section{Copyrights}

Copyright for this article is retained by the author(s), with first publication rights granted to the journal.

This is an open-access article distributed under the terms and conditions of the Creative Commons Attribution license (http://creativecommons.org/licenses/by/4.0/). 